\title{
The Prevalence of Balantidium coli Infection in Fifty-Six Mammalian Species
}

\author{
Kiyoshi NAKAUCHI \\ Ken-sei Meat Inspection Office, 584 Ichinobe, Shimodate, Ibaraki 308-0827, Japan \\ (Received 6 August 1998/Accepted 9 September 1998)
}

ABSTRACT. A total of 375 fecal samples of 56 mammalian species belonging to 17 families of 4 orders were examined for the detection of Balantidium coli from December 1994 to August 1995. As a result, B. coli was found from 6 species belonging to 4 families of 2 orders (Primates and Artiodactyla) of host animals examined. White-handed gibbon (Hylobates lar), squirrel monkey (Saimiri sciurea) and Japanese macaque (Macaca fuscata) were new hosts for B. coli. All the wild boar (Sus scrofa) and chimpanzee (Pan troglodytes) examined were positive. The highest number of $B$. coli was obtained from a chimpanzee $(1,230 / \mathrm{g}$ feces). No $B$. coli was detected from the animals of orders Rodentia and Carnivora including dogs and cats. The rarity of $B$. coli infection in breeding animals in Japan suggests that there is no serious problem in controlling infections.—KEY wORDs: Balantidium coli, feces, prevalence.

J. Vet. Med. Sci. 61(1): 63-65, 1999

Balantidium coli is widespread throughout the world and has a wide variety of hosts, including man, various domestic and wild mammals [1-8, 10-28]. Rarely the protozoa causes diarrhea or dysentery, and produces ulcerative lesions in the large intestine $[3,7,12]$. In Japan, the prevalence of $B$. coli has been reported in pigs $[16,17]$ and cynomolgus monkeys [18]. However, there is little information on the prevalence of $B$. coli in the other various animal species. The present paper deals with the prevalence of $B$. coli in various animals bred in Japan by fecal examination.

During the period from December 1994 to August 1995, a total 375 fecal samples were collected from the healthy animals: 56 species belonging to 17 families of 4 orders (Table 1), including 100 stray cats (Felis catus), 100 stray dogs (Canis familiaris) and 50 Japanese macaques (Macaca fuscata) in a large established monkey colony (22 Japanese macaques in individual cage). Stray cats and dogs were committed to Animal Administrative Guidance Center of Ibaraki Prefecture. All animals were born and/or bred in Ibaraki Prefecture, Japan. For detection of B. coli, $3 \mathrm{~g}$ of the fresh feces were fixed and stained with $6 \mathrm{ml}$ of methylgreen-formalin-saline (MFS) solution [19] as soon as

Table 1. Orders, families, species and number of animals examined

\begin{tabular}{|c|c|c|}
\hline Order & Family & Species (No. of Samples) \\
\hline \multirow[t]{6}{*}{ Primates } & Lemuridae & Lemur catta (1), Lemur variegatus (1), Lemur mongoz (1) \\
\hline & Galagidae & Galago crassicaudatus (1) \\
\hline & Cebidae & Cebus apella (1), Saimiri sciurea (2) \\
\hline & Callithricidae & Callithrix jacchus (1), Saguinus midas (1), Leontocebus oedipus (2) \\
\hline & Cercopithecidae & $\begin{array}{l}\text { Macaca fuscata (72), Macaca irus (2), Macaca mulatta (4), } \\
\text { Macaca cyclopsis (1), Macaca nemestrina (4), Cynopithecus niger (1), } \\
\text { Comopithecus hamadryas (4), Cercopithecus aethiops (1), } \\
\text { Cercopithecus neglectus (1), Papio doguera (1), } \\
\text { Cercopithecus nictitans (1) }\end{array}$ \\
\hline & Pongidae & $\begin{array}{l}\text { Hylobates lar (4), Hylobates concolors (2), Pan troglodytes (3), } \\
\text { Gorilla gorilla (1) }\end{array}$ \\
\hline \multirow[t]{2}{*}{ Rodentia } & Hystricidae & Hystrix cristata $(1)$ \\
\hline & Caviidae & Dolichotis patagona (1) \\
\hline \multirow[t]{8}{*}{ Carnivora } & Canidae & $\begin{array}{l}\text { Canis familiaris (100), Canis lupus (1), Alopex lagopus (1), } \\
\text { Vulpes vulpes (5), Urocyon cinereoargentatus (1), } \\
\text { Nyctereutes procyonoides (4) }\end{array}$ \\
\hline & Ursidae & $\begin{array}{l}\text { Selenarctos thibetanus (4), Ursus arctos (3), Thalarctos maritimus (1), } \\
\text { Melursus ursinus (1) }\end{array}$ \\
\hline & Procyonidae & Procyon lotor (5), Ailurus fulgens (2) \\
\hline & Mustelidae & $\begin{array}{l}\text { Martes melampus (1), Meles meles (2), Taxidea taxus (1), } \\
\text { Mephitis macroura (2) }\end{array}$ \\
\hline & Viverridae & Paguma larvata (2), Civettictis civetta (1), Suricata suricatta (1) \\
\hline & Hyaenidae & Crocuta crocuta (1), Hyaena hyaena (2) \\
\hline & Feridae & $\begin{array}{l}\text { Felis catus }(100), \text { Felis lynx (1), Prionailurus bengalensis }(2), \\
\text { Panthera pardus ( } 3), \text { Panthera onca (1), Panthera tigris }(2), \\
\text { Panthera leo }(5)\end{array}$ \\
\hline & Phocidae & Phoca vitulina (1) \\
\hline Artiodactyla & Suidae & Sus scrofa (4) \\
\hline
\end{tabular}

Total No. of Species 56, Total No. of Samples 375. 
Table 2. A list of animals positive for Balantidium coli

\begin{tabular}{|c|c|c|c|c|c|}
\hline \multirow[t]{2}{*}{ Order } & \multirow[t]{2}{*}{ Species } & \multirow[t]{2}{*}{ Sex } & \multirow[t]{2}{*}{ Age } & \multicolumn{2}{|c|}{ No. of Balantidium coli (/g feces) } \\
\hline & & & & Trophozoite & Cyst \\
\hline \multirow[t]{8}{*}{ Primates } & Chimpanzee & $\mathrm{ND}^{\mathrm{a})}$ & ND & 150 & 1080 \\
\hline & (Pan troglodytes) & ND & ND & 0 & 150 \\
\hline & & ND & ND & 300 & 450 \\
\hline & White-handed & $\mathrm{M}^{\mathrm{b})}$ & $\mathrm{A}^{\mathrm{c})}$ & 0 & 60 \\
\hline & $\begin{array}{c}\text { gibbon } \\
\text { (Hylobates lar })\end{array}$ & $\mathrm{F}^{\mathrm{d})}$ & A & 0 & 30 \\
\hline & $\begin{array}{l}\text { Squirrelmonkey } \\
\text { (Saimiri sciurea) }\end{array}$ & ND & $\mathrm{ND}$ & 0 & 30 \\
\hline & $\begin{array}{l}\text { Sacred baboon } \\
\text { mopithecus hamadryas) }\end{array}$ & $F$ & A & 0 & 30 \\
\hline & $\begin{array}{l}\text { Japanese macaque } \\
\text { (Macaca fuscata) }\end{array}$ & $\mathrm{F}$ & A & 30 & 60 \\
\hline \multirow[t]{4}{*}{ Artiodactyla } & Wild boar & $\mathrm{F}$ & A & 0 & 420 \\
\hline & (Sus scrofa) & $\mathrm{F}$ & A & 0 & 270 \\
\hline & & $\mathrm{F}$ & A & 0 & 120 \\
\hline & & $\mathrm{F}$ & A & 0 & 90 \\
\hline
\end{tabular}

a) Not defined. b) Male. c) Adult. d) Female.

possible after collection. They were then filtered through a double-folded sheet of muslin, and kept at room temperature until microscopic examination. The identification of $B$. coli was in accordance with the descriptions by Flynn [7] and Levine [12]. For counting $B$. coli organisms, a planktoncounter glass slide was used [19].

The results of animals positive for $B$. coli are shown in Table 2. Six species belonging to 4 families of 2 orders (Primates and Artiodactyla) of the animals examined were $B$. coli positive. In the present survey, B. coli was not detected from the orders Rodentia and Carnivora. Each animal positive for $B$. coli was kept in an individual cage at the rearing facility of zoos after wild caught or born in zoos except Japanese macaque (Macaca fuscata). Japanese macaque positive for $B$. coli was raised as a pet. The highest positive rate occurred in wild boar (Sus scrofa), 4 of 4 (100\%), and chimpanzee (Pan troglodytes), 3 of 3 (100\%), and the highest number of 1230 (trophozoite 150, cyst 1080) per gram of feces was detected in a chimpanzee. The clinical manifestations such as diarrhea were not observed in all the animals examined.

$B$. coli is common parasites of several nonhuman primates, including the African green monkey [22], baboon [14], capuchin [7, 27], chimpanzee [11, 26], cynomolgus monkey [18], gorilla [24], howler monkey [7], Indian monkey [21], orangutan [4], rhesus monkey [8, 9, 28], and spider monkey [7] throughout the world. In the present survey, B. coli was found from 5 species out of 24 nonhuman primate species. White-handed gibbon (Hylobates lar), squirrel monkey (Saimiri sciurea) and Japanese macaque (Macaca fuscata) are new hosts for $B$. coli. While in the feces of Japanese macaque in a large established monkey colony $B$. coli was not detected. On the other hand, all fecal samples of the chimpanzee examined were $B$. coli positive. $B$. coli is a commonlyfound protozoan parasite of chimpanzees [11]. It was reported that the prevalence of $B$. coli infection in 49 chimpanzees was 33\% [26]. In another report, high incidence $(84 \%)$ of $B$. coli infection has been reported in the chimpanzee [7]. The parasite has been also detected from $9.0 \%$ of the cynomolgus monkey [18] and $1.5 \%$ of African green monkey [22]. Therefore, it is assumed that the susceptibility of chimpanzee to $B$. coli infection is higher than that of the other nonhuman primates.

$B$. coli is often found from domestic and wild hogs [1, 3]. In the present study, all the wild boars examined were also positive for $B$. coli. The high prevalence of this parasite in domestic pigs was described by many authors $[1,16,17$, 20,25]. At the same time, it is reported that B. coli infection occurs in their early stage of life in pigs [17]. Since pig and wild boar are the same species of animal, it is considered that the wild boars are also infected with $B$. coli in their early life stage similarly in pigs.

B. coli has been also reported from the orders Rodentia and Carnivora, such as capybara [13], cat [2], dog [2, 5, 6, 10], hamster [23], and rat [1,15]. Awakian [1] reported that $B$. coli was found in $29 \%$ of Moscow rats. In the present results, B. coli was detected in neither orders, Rodentia nor Carnivora including dogs and cats.

The rarity of $B$. coli infection in healthy animals bred in Japan suggests that there is no serious problem in controlling infections.

\section{REFERENCES}

1. Awakian, A. 1937. Trans. R. Soc. Trop. Med. Hyg. 31: 93-98.

2. Bailey, W. S. and Williams, A. G. 1949. J. Am. Vet. Med. Assoc. 114: 238.

3. Beaver, P. C., Jung, R. C. and Cupp, E.W. 1984. pp. 213217. In: Clinical Parasitology, 9th ed., Lea \& Febiger, Philadelphia.

4. Brooks, H. 1903. Proc. New York Pathol. Soc. 3: 28.

5. Dinkmans, G. 1948. Proc. Helm. Soc. Washington 15: 40-41. 
6. Ewing, S.A. and Bull, R.W. 1966. J. Am. Vet. Med. Assoc. 149: 519-520.

7. Flynn, R. J. 1973. Parasites of Laboratory Animals, Iowa State Univ. Press, Ames, Iowa

8. Gisler, D. B., Benson, R. E. and Young, R. J. 1960. Ann. New York Acad. Sci. 85: 758-768.

9. Habermann, R. T. and Williams, F. P. Jr. 1957. Am. J. Vet Res. 18: 419-426.

10. Hayes, F. A. and Jordan, H. E. 1956. J. Am. Vet. Med. Assoc. 129: 161.

11. Kim, J. C. S., Abee, C. R. and Wolf, R. W. 1978. Lab. Anim 12: $231-233$

12. Levine, N. D. 1973. pp. 369-371. In: Protozoan Parasites of Domestic Animals and of Man, 2nd ed., Burgess Publ. Co., Minneapolis.

13. Moulton, J. E., Heuschele, W. P. and Sheridan, B. W. 1961 Cornell Vet. 51: 350-358.

14. Myers, B. J. and Kuntz, R. E. 1968. J. Protozool. 15: 363-365.

15. Nagahama, M. 1932. J. Chosen Med. Assoc. 22: 75-77.

16. Nakauchi, K. 1990. Jpn. J. Parasitol. 39: 351-355.

17. Nakauchi, K. 1991. J. Vet. Med. Sci. 53: 967-968.
18. Nakauchi, K., Nakajima, H. and Sakakibara, I. 1990. Jpn. J. Vet. Sci. 52: 1323-1324.

19. Ogimoto, K. and Imai, S. 1981. Atlas of Rumen Microbiology, Japan Scientific Societies Press, Tokyo.

20. Pritze, F. 1928. Z. Parasit. 1: 345-415.

21. Qadri, S. S. and Navarathram, E. S. 1966. Riv. Parasitol. 27: 89-96.

22. Reardon, L. V. and Rininger, B. F. 1968. Lab. Anim. Care 18: $577-580$

23. Sheffield, F. W. and Beveridge, E. 1962. Nature (Lond.)196: 294-295.

24. Teare, J. A. and Loomis, M. R. 1982. J. Am. Vet. Med. Assoc. 181: 1345-1347.

25. Van der Hoeven, J. A. and Rijpstra, A. C. 1957. Doc. Med. Georgr. Trop. 9: 225-228.

26. Van Riper, D. C., Day, P. W., Fineg, J. and Prine, J. R. 1966. Lab. Anim. Care 16: 360-363.

27. Wenyon, C. M. 1926. Protozoology, Bailliere, London.

28. Young, R. J., Fremming, B. D., Benson, R. E. and Harris, M. D. 1957. Proc. Anim. Care Panel 7: 67-82. 